\title{
Penanganan Trigeminocardiac Reflex (TCR) selama Anestesi untuk Bedah Saraf
}

\author{
Dewi Yulianti Bisri \\ Departemen Anestesiologi dan Terapi Intensif Fakultas Kedokteran Universitas Padjadjaran Bandung
}

\begin{abstract}
Abstrak
Trigeminocardiac reflex (TCR) adalah suatu reflex batang otak unik yang manifest sebagai pertubasi cardiorespiratori negatif. Trigeminocardiac reflex didefinisikan sebagai kejadian tiba-tiba dari disritmia parasimpatetik, hipotensi simpatetik, apnea, atau hipermotilitas gastrik selama stimulasi cabang sensoris dari saraf trigeminal. Secara klinis, TCR telah dilaporkan terjadi pada semua prosedur bedah yang dipersarafi oleh saraf trigeminal. Refleks ini telah dilaporkan terjadi pada operasi skull base (dasar tengkorak), akan tetapi, baru-baru ini, juga berhubungan dengan banyak operasi bedah saraf yang lain, prosedur neurointervensional, juga pada operasi bukan bedah saraf dan pada keadaan tidak dioperasi. Refleks ini menunjukkan perubahan kardiovaskular yang menimbulkan komplikasi katastropik, memperburuk outcome, juga merupakan dilema dalam menegakkan diagnosis. Walaupun terdapat banyak literatur dengan laporan insidensi dan faktor risiko dari TCR, signifikansi fisiologis an fungsi belum sepenuhnya dapat dijelaskan. Sebagai tambahan, ada hal yang kompleks dalam TCR yang memerlukan pengkajian dan klarifikasi. Bila terjadi TCR dapat dilakukan terapi dengan identifikasi dan modifikasi faktor risiko, penilaian kedalaman anestesi, pengobatan profilaksis dengan agen vagolitik atau blok saraf perifer jika terjadi manipulasi saraf perifer, pemantauan kardiovaskular yang cermat selama anestesi, terutama pada mereka yang memiliki faktor risiko TCR, penghentian manipulasi, dan pemberian agen vagolitik dan adrenalin. Karena itu, pada tulisan ini akan disampaikan tentang mekanisme, definisi, patofisiologi, manifestasi, diagnosis dan tatalaksananya.
\end{abstract}

Kata kunci: Trigeminocardiac reflex, simpatetik-parasimpatetik, bedah saraf, vagolitik

JNI 2021; 10 (3): 214-227

\section{Trigeminocardiac Reflex (TCR) Management during Anesthesia for Neurosurgery}

\begin{abstract}
Trigeminocardiac reflex (TCR) is a unique brain stem reflex that manifests as negative cardio-respiratory perturbations. The trigeminocardiac reflex (TCR) is defined as the sudden onset of parasympathetic dysrhythmia, sympathetic hypotension, apnea, or gastric hypermotility during stimulation of any of the sensory branches of the trigeminal nerve. Clinically, the TCR has been reported in all the surgical procedures in which a structure innervated by the trigeminal nerve is involved. This reflex is largely reported in skull base surgeries/interventions; however, in recent times, it has been also linked with many neurosurgical, neurointerventional procedures, non-neurosurgical and non-surgical conditions. This reflex presents with many cardiovascular changes that can create catastrophic complications, worse outcome as well as diagnostic dilemmas. Although, there is an abundant literature with reports of incidences and risk factors of the TCR; the physiological significance and function of this brainstem reflex has not yet been fully elucidated. In addition, there are complexities within the TCR that requires examination and clarification. If a CTR occurs, it can risk factor identification and modification, depth of anesthesia assessment, prophylactic treatment with either vagolytic agents or peripheral nerve block in case of peripheral manipulations of the nerve, careful cardiovascular monitoring during anesthesia, especially in those with a risk factor for TCR, treatment of the condition when it occurs: cessation of the manipulation, and administration of vagolytic agents and adrenaline. Therefore, this narrative review intends to elaborate on its mechanisms, definition, pathophysiology, manifestations, diagnosis and management.
\end{abstract}

Key words: Trigeminocardiac reflex, simpatetik-parasimpatetik, bedah saraf, vagolitik

JNI 2021; 10 (3): 214-227

This article is licensed under a

Creative Commons Attribution-NonCommercial-ShareAlike 4.0 International License.

CDewi Yulianti B

(2021) under the CC-BY-NC-SA license 


\section{Pendahuluan}

Refleks trigeminokardiak (Trigeminocardiac reflex/TCR) adalah salah satu refleks batang otak paling kuat yang terkait dengan stimulasi salah satu divisi sensorik saraf trigeminal. ${ }^{1}$ Refleks ini telah diberi banyak nama termasuk trigeminodepressor, trigeminovagal, refleks okulokardiak, dll. Responnya dapat ditimbulkan oleh stimulasi bagian manapun dari cabang sensorik saraf kelima sepanjang jalur intrakranial atau ekstrakranialnya. ${ }^{1}$ Trigeminocardiac reflex menyebabkan beragam manifestasi dari hipotensi hingga hipertensi, bradikardi hingga asistol, bradipnea hingga apneu dan perubahan motilitas lambung. ${ }^{1-12}$

Terjadinya aritmia jantung yang tiba-tiba sampai henti jantung, hipotensi arteri, apnea dan hipermobilitas lambung sebagai manifestasi TCR, awalnya dijelaskan pada tahun 1870 oleh Kratschmer et al, setelah manipulasi mukosa hidung pada kucing dan kelinci dan disebut sebagai Kratschmer's reflex. Pada tahun 1908, Bernhard Aschner dan Guiseppe Dagnini mempresentasikan oculocardiac reflex (OCR) sehingga disebut juga fenomena Aschner- saat itu dianggap sebagai deskripsi awal dari subtipe TCR perifer yang mendapat perhatian luas dokter mata. Pada tahun 1977 Kumada et al, mendeskripsikan respon otonom "depresor trigeminal" yang serupa setelah stimulasi listrik frekuensi rendah pada bagian kompleks trigeminal kelinci yang dibius atau decerebrated, menandakan bahwa tidak hanya perifer tetapi juga stimulasi sentral jalur trigeminal menghasilkan respons refleks otonom. Pada tahun 1988 istilah "trigeminocardiac reflex" diperkenalkan oleh ahli anestesi Shelly dan Church. Pada tahun 1999, Schaller et al, menggambarkan terjadinya TCR sentral pada manusia setelah stimulasi bagian tengah saraf trigeminal selama operasi cerebellopontine angle dan batang otak. ${ }^{2,3}$ Pada awalnya, refleks ini terutama ditekankan dalam prosedur bedah saraf (terutama, operasi dasar tengkorak), tetapi sekarang telah dieksplorasi di banyak domain lain, tidak terbatas pada batas-batas periode intraoperatif tetapi diselidiki di banyak prosedur non-bedah saraf atau bedah lainnya. Refleks ini muncul dengan gangguan kardiovaskular dan dapat menimbulkan komplikasi katastropik dan dilema diagnostik bagi dokter lain, sehingga menjadi penting untuk memahami dan mengetahui mekanisme, definisi, patofisiologi, faktor predisposisi, manifestasi, diagnosis, dan penatalaksanaan TCR. ${ }^{1}$

Saraf kranial kelima adalah yang terbesar dari semua saraf kranial dan menyediakan suplai sensorik wajah, kulit kepala, sinus dan mukosa hidung dan mulut serta duramater tengah, anterior dan bagian dari fossa kranial posterior. Stimulasi pada salah satu bagian sensorik saraf trigeminal telah terbukti memulai TCR dan juga menyebabkan berbagai aritmia jantung selain gejala lain yang kurang mengancam jiwa. Awalnya, refleks ini telah dipelajari pada hewan dan oleh karena itu dikenal selama lebih dari satu abad, di bawah istilah "trigemino-respiratory reflex" dan sekarang bangkit kembali sebagai sudden infant death syndrome (SIDS). Pada awal abad ke-20, TCR telah berkembang pesat dan lebih sedikit perhatian eksperimental berupa OCR yang merupakan respon jantung terkait dengan stimulasi divisi oftalmikus trigeminal saraf selama operasi mata. ${ }^{5}$ Trigeminocardiac reflex telah mendapat perhatian luas di bidang bedah saraf. Dalam beberapa tahun terakhir, TCR telah dilaporkan terjadi pada prosedur bedah saraf lainnya seperti bedah transsphenoidal, Jannetta dekompresi mikrovaskular, percutaneous radiofrequency thermocoagulation dan percutaneous microcompression dari ganglion trigeminal, pendekatan neuroendovaskular dalam bedah saraf, dan selama kliping aneurisma. ${ }^{2}$

\section{Epidemiologi}

Trigeminocardiac reflex terjadi dengan manipulasi mekanis/termal di sekitar salah satu cabang saraf trigeminal, dengan prevalensi spesifik di lokasi anatomi tertentu. Oculocardiac reflex menjadi sub-varian dari TCR perifer telah dipelajari secara ekstensif sebelumnya dan disebutkan terjadi hingga $67 \%$ operasi mata. Karena bias publikasi, prevalensi sebenarnya mungkin jauh lebih kecil, bahkan TCR perifer umumnya memiliki prevalensi lebih tinggi 
daripada TCR sentral. Trigeminocardiac reflex sentral terjadi pada $10-18 \%$ pasien. Dalam review time-series retrospektif dari 125 pasien yang dioperasi untuk tumor dari cerebellopontine angle, kejadian TCR sekitar 11\%. Tiga dari pasien dalam seri ini terjadi asistol yang berlangsung dari 30 hingga 70 detik. ${ }^{5}$ Dalam studi retrospektif lainnya, diteliti kejadian TCR selama dekompresi mikrovaskular dari saraf trigeminal untuk neuralgia trigeminal. Di dalam review pada 28 pasien, prevalensi TCR naik hingga $18 \%$ dengan definisi yang sama yang digunakan dalam penelitian sebelumnya. TCR juga dilaporkan selama operasi transsphenoidal untuk adenoma hipofisis. Diantara 117 pasien yang menjalani operasi transsphenoidal untuk adenoma hipofisis, $10 \%$ terjadi TCR selama prosedur pembedahan. Stimulasi perifer pada nasofaring juga dapat menyebabkan TCR (perifer). ${ }^{5}$ Karena TCR telah dibuktikan dapat dipicu di titik manapun selama berlangsung pembedahan, saraf trigeminal dapat diamati selama beberapa pendekatan bedah yang berbeda di lapangan operasi kraniofasial dan neurologis yang melibatkan manipulasi struktur yang dipersarafi oleh saraf trigeminal atau saraf trigeminal itu sendiri.

\section{Faktor Risiko dan Predisposisi}

Faktor predisposisi dan risiko TCR adalah anak-anak, laki-laki, aktivitas simpatis tinggi, hipoksemia, hiperkarbia, anestesi ringan, penghambat neuromuskuler, opioid, betablocker, calcium-channel blocker, clonidine, digoxin, antikonvulsan, lithium, agen lain yang dapat menyebabkan bradikardia. Gangguan metabolisme seperti hipoksia, hipotermia, asidosis, hiperkalemia, hiperkalsemia, gangguan endokrinologis seperti hipotiroid dapat memicu refleks ini. Penyebab lain bradikardia bisa karena cedera kepala traumatis, salah satu tanda dari cushings triad, selama peningkatan tekanan intrakranial, perdarahan, kompresi vermis serebelar yang dapat menyebabkan penurunan aktivitas simpatis, pada cedera saraf tulang belakang servikal. ${ }^{1,5,8}$ Menariknya, stimulasi bilateral pada struktur yang dipersarafi trigeminal atau serabut saraf trigeminal menyebabkan refleks yang lebih dalam daripada stimulasi unilateral.
Bahkan meskipun faktor risiko yang disebutkan sebelumnya didasarkan pada penelitian yang dilakukan hampir 30 tahun lalu, mereka dapat diidentifikasi lagi dalam publikasi terbaru tentang topik ini. Spiriev dkk. mengamati TCR perioperatif pada dasar empiema subdural atau paparan $\mathrm{H}_{2} \mathrm{O}_{2}$, menunjukkan bahwa bahan kimia atau rangsangan inflamasi mungkin merupakan faktor predisposisi. Obat-obatan termasuk agen narkotik yangkuat seperti sufentanil danalfentanil, beta-blocker dan calsium channel blocker, telah dilaporkan menjadi predisposisi TCR karena menghambat sistem saraf simpatis (narkotika poten), menurunkan respon simpatis jantung (beta-blocker) dan menyebabkan vasodilatasi arteri perifer yang mengakibatkan penurunan laju jantung (heart rate/HR) dan tekanan darah arteri rata-rata (mean arterial blood pressure/ MABP). Namun, bukti dampak dari obat tersebut adalah rendah, karena efek tidak dapat dikonfirmasi dalam literatur yang lebih baru. Berdasarkan temuan ini, telah dikembangkan konsep bahwa sebagian besar faktor risiko mengarah pada sensitisasi saraf trigeminal dan membuatnya lebih rentan memicu TCR selama stimulasi intraoperatif. Namun, sebagai obat predisposisi secara aktif mempengaruhi keseimbangan arus keluar otonom, efeknya lebih diterapkan melalui modulasi jalur refleks eferen daripada pada pengurangan ambang penerimaan jalur aferen. ${ }^{2}$

\section{Definisi dan Diagnosis}

Trigeminocardiac reflex adalah refleks otonom yang diatur oleh batang otak, yang melibatkan tiga komponen anatomi utama: divisi sensorik saraf kelima, nuclei batang otak, dan saraf vagus. Sebagai hasil dari rangsangan saraf trigeminal (di mana saja sepanjang perjalanannya) ia mendorong dan biasanya bermanifestasi sebagai perkembangan tiba-tiba dari gangguan jantung (terutama negatif) termasuk bradikardia, asistol, dan hipotensi. Karena refleks ini terutama dilaporkan dan dipelajari secara intraoperatif dengan anestesi umum, gejala lain yang dideskripsikan secara klasik (apnea, hipermotilitas lambung) mungkin belum diketahui sejauh ini, karena sebagian besar penelitian dilakukan selama operasi. 
Definisi klasik dari TCR adalah penurunan tekanan darah arteri rata-rata dan denyut jantung lebih dari $20 \%$ dari nilai dasarnya dan harus bertepatan dengan stimulasi saraf trigeminal. Untuk menentukan terjadinya TCR, adanya penurunan MABP, dan HR lebih dari 20\% dibandingkan dengan rentang basal, dipertahankan selama operasi, dianggap signifikan. Karakteristik utama dari TCR adalah dengan penghentian manipulasi akan mengarah pada normalisasi MABP dan laju jantung dan dapat terjadi lagi setelah dimulainya kembali manipulasi. Terjadinya bradikardia saja tanpa hipotensi tidak dapat disebut sebagai TCR. ${ }^{6}$ Namun, definisi ini tampaknya bermasalah karena tolok ukur $20 \%$ agak sewenang-wenang dan menyiratkan bahwa perubahan kurang dari nilai ini tidak didefinisikan sebagai TCR, yang mengaburkan insiden yang sebenarnya dan menyebabkan perkiraan TCR yang terlalu rendah dalam praktek klinis operasi sehari-hari. Untuk klasifikasi selanjutnya, subtipe TCR dapat didefinisikan berdasarkan titik pemicu di dekat sistem saraf pusat atau di cabang saraf tepi. TCR sentral (proksimal) dipicu saat stimulasi jalur intrakranial saraf trigeminal, yaitu dari ganglion Gasserian ke batang otak. TCR perifer (distal) didapat dari stimulasi saraf trigeminal di mana saja sepanjang perjalanannya di luar tempurung kepala ke ganglion Gasserian. Periferal TCR selanjutnya dibagi lagi berdasarkan cabang saraf trigeminal yang terkena membedakan refleks oftalmokardiak (OCR) dan refleks maxillomandibulocardiac (MCR). ${ }^{6}$

Manifestasi TCR ringan tidak dapat dirangkum dengan definisi ini, namun, harus dicatat bahwa kejadian TCR yang tampak, biasanya terjadi dengan perubahan hemodinamik yang signifikan. Yang penting, terkadang, beberapa episode TCR dapat terjadi tanpa tanda peringatan sebelumnya; misalnya, stimulasi intens yang tiba-tiba pada bagian tengah saraf kranial kelima dapat menghasilkan asistol tanpa tanda peringatan bradikardia atau hipotensi. Karena episode TCR menghasilkan perubahan hemodinamik yang serupa seperti yang ditimbulkan oleh berbagai faktor umum lainnya termasuk fisiologis, anestesi, perdarahan, emboli udara vena, anafilaksis, dan faktor terkait posisi, telah mengembangkan definisi yang lebih valid dari TCR didasarkan pada dua kriteria mayor (masuk akal, reversibilitas) dan dua minor (pengulangan, pencegahan). Definisi yang ditetapkan pada kriteria ini dapat digunakan untuk menghilangkan penyebab lain. ${ }^{1}$ Sejakpertamakalidideskripsikan pada tahun 1999, TCR didefinisikan sebagai gejala parasimpatis yang muncul secara tiba-tiba berupa disritmia, hipotensi simpatis, apnea atau hiper-motilitas lambung selama stimulasi dari salah satu cabang sensorik dari saraf trigeminal. Mekanisme dasar

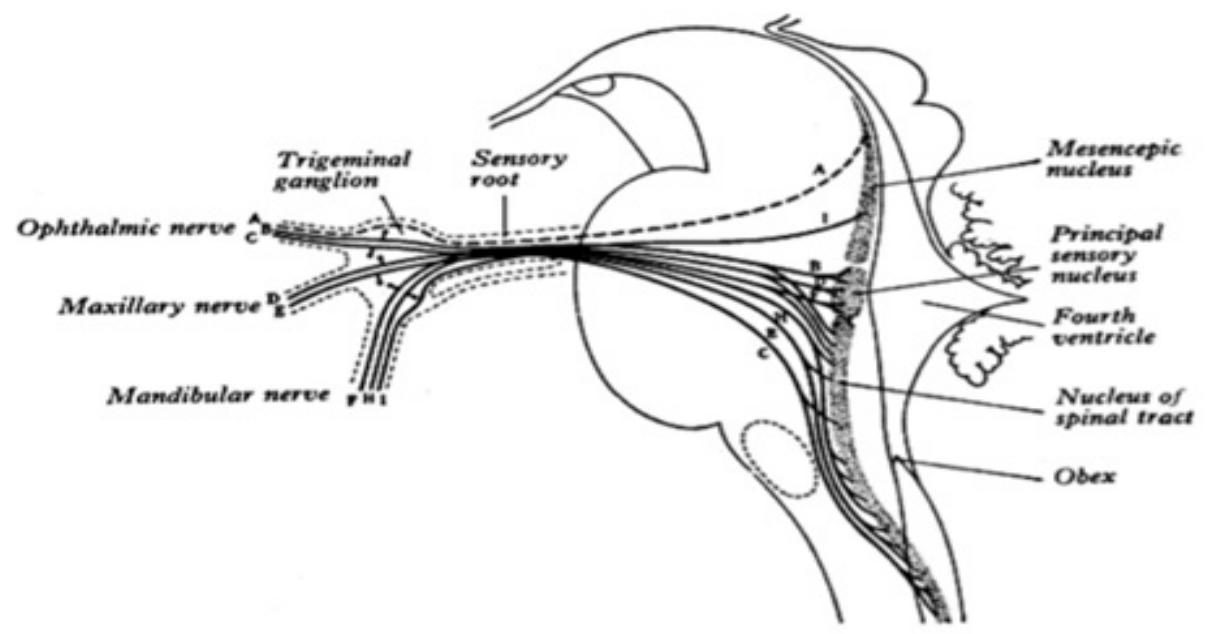

Figure 1. Trigeminal nerve with trigeminal ganglion and nuclei (from Warwick, R, Williams PL. Gray's Anatomy, 35th ed, p 1001, Edinburgh, Churchill Livingstone, 1973)

Gambar 1.

Dikutip dari: Chowdhury T. ${ }^{5}$ 
yang diusulkan untuk pengembangan TCR adalah sinyal yang dikirim oleh ujung saraf sensorik dari saraf trigeminal melalui ganglion Gasserian ke inti sensorik saraf trigeminal, membentuk jalur aferen dari busur refleks. Jalur aferen ini berlanjut di sepanjang serabut saraf internuncial pendek dalam formasi retikuler pons untuk terhubung dengan jalur eferen pada inti motorik saraf vagus di nukleus ambigus (lihat Gambar 1). Beberapa bukti eksperimental menunjukkan bahwa refleks kardiovaskular yang diinduksi trigeminal dapat menjadi rangsangan yang ditimbulkan pada awalnya di nukleus trigeminal caudalis dan kemudian di nukleus parabrachial, ventrolateral rostral medulla oblongata, bidang retikuler meduler dorsal dan nukleus paratrigeminal. ${ }^{5}$

Menurut pengetahuan saat ini, TCR terjadi selama manipulasi saraf trigeminal perifer dan sentral serta manipulasi di sekitar Ganglion Gasseri. Oculo cardiac reflex yang merupakan subbentuk perifer dari TCR, telah dilaporkan pada pasien dengan operasi mata dan manipulasi saraf trigeminal berturut-turut sejak beberapa dekade. Setelah 1999, Schaller et al., untuk pertama kalinya, melaporkan terjadinya TCR pada operasi dasar tengkorak dan neurologis, diperkirakan bahwa OCR dan TCR adalah refleks yang sama. Mekanisme seluler yang mendasari belum sepenuhnya dipahami, tetapi diyakini menjadi sama dengan TCR yang dilaporkan sebelumnya secara lebih rinci selama aktivasi pusat atau bagian intrakranial dari saraf trigeminal. ${ }^{5}$ Trigeminocardiac reflex muncul hanya sebagai akibat dari rangsangan fisik struktur okular dan periokular yang dipersarafi oleh saraf oftalmikus, yang merupakan pembelahan saraf trigeminal. Mekanisme yang diterima untuk terjadinya TCR adalah ketika manipulasi mekanis, peregangan, efek tekanan terjadi pada salah satu dari tiga cabang atau cabang perifer, ujung saraf sensorik dari saraf trigeminal mengirim impuls melalui ganglion Gasserian ke nukleus sensorik trigeminal. Lengan aferen terhubung ke lengan eferen melalui serabut internuncial pendek dalam formasi retikuler dan menghubungkan nukleus motorik viseral dari saraf vagus. Setelah ini, sinyal melewati daerah rostral ventral lateral dan intermediate ventral lateral medula dan ke pons dorsolateral. Impuls berlanjut melalui kolom sel intermediolateral dari medulla spinalis, mengirimkan sinyal melalui saraf asal vagus ke organ ujung aktif seperti jantung dan perut. Impuls ini meningkatkan aktivitas parasimpatis jantung dan sistem gastrointestinal. Jalur eferen berjalan di sepanjang saraf vagus melalui pusat kardiovaskular dari medula ke nodus sinoatrial. ${ }^{8}$

Jalur eferen berjalan dan berakhir di 2 reseptor muskarinik jantung yang menyebabkan efek kronotrofik dan inotrofik negatif yang dimediasi oleh vagus pada jantung. Tungkai eferen juga terhubung ke lambung yang meningkatkan motilitas lambung. Refleks trigeminokardiak adalah proses internal tubuh untuk mencegah desaturasi oksigen di otak. Saraf simpatis dirangsang yang menyebabkan peningkatan aliran darah, tetapi dapat menyebabkan penurunan aliran darah di jantung yang menyebabkan asistole dan aritmia ventrikel. Stimulasi refleks ini dapat memicu sinus bradikardia mendadak, bradikardia berakhir sebagai asistol, asistol tanpa bradikardia dan hipotensi sebelumnya. Ada dua jenis refleks trigeminokardiak, sentral dan perifer. Tipe sentral diinduksi oleh stimulasi ganglion Gasserian, yang menyebabkan bradikardia, apnea, dan hipotensi. Tipe perifer memiliki tiga subtipe, OCR, refleks jantung rahang atas-rahang bawah (keduanya menginduksi bradikardia, apnea dan normotensi) dan tipe ketiga adalah diving refleks yang distimulasi oleh saraf ethmoidal anterior yang menginduksi bradikardia, apnea dan hipertensi. ${ }^{8}$

\section{Faktor Pemicu}

Setiap prosedur pembedahan di dalam dan di sekitar area distribusi cabang saraf trigeminal manapun dapat memicu TCR. Beberapa prosedur bedah yang dilaporkan adalah operasi mata, operasi kraniofasial, operasi dasar tengkorak, operasi gigi, rhizolisis trigeminal dan prosedur lain di kepala. Menariknya, beberapa episode TCR yang dilaporkan sama sekali tidak terkait dengan operasi besar, tetapi dengan prosedur yang relatif kecil seperti penjahitan kulit, fiksasi pin tengkorak, dan blok saraf kulit kepala. Hampir semua literatur yang terkait dengan TCR menggambarkannya 
sebagai fenomena intraoperatif akut; namun, baru-baru ini menekankan adanya bentuk kronis refleks ini. Presentasi TCR kronis ini sering kali menghasilkan beberapa gejala yang melemahkan, yang menyebabkan kesulitan dalam mendiagnosis fenomena ini. ${ }^{1}$

Berbagai faktor pemicu telah dilaporkan mempengaruhi episode TCR secara langsung atau tidak langsung. Faktor-faktor ini termasuk hiperkapnia, hipoksemia, kedalaman anestesi (anestesi dangkal/light anesthesia), kelompok usia yang lebih muda (dengan tonus vagal istirahat tinggi), narkotika, penggunaan betablocker praoperasi dan calcium channel blocker, dan asidosis. Beberapa faktor intraoperatif seperti anestesi ringan, hiperkarbia, hipoksia dan asidosis dapat diperbaiki, oleh karena itu, hal ini perlu ditangani dengan segera. Penelitian terbaru menekankan pentingnya kedalaman anestesi dalam konteks kejadian TCR dan telah menyarankan bahwa light anesthesia merupakan faktor risiko potensial untuk kejadian episode TCR. Ada hubungan yang lebih kuat antara light anesthesia dan lebih banyak episode asistol dibandingkan dengan anestesi yang dalam. Studi ini lebih lanjut menekankan bahwa hampir 4,5 kali lipat risiko asistol pada subkelompok light anesthesia untuk terjadi TCR. Dalam laporan lain, episode TCR digagalkan oleh bolus propofol. Apakah meningkatkan kedalaman dengan agen volatil akan menghasilkan penghapusan refleks yang serupa seperti yang terlihat dalam kasus dengan propofol adalah masalah penelitian lebih lanjut. ${ }^{1}$ Sebagian besar strategi pencegahan dilaporkan untuk varian perifer (okulokardiak) dari TCR. Beberapa penelitian menekankan penggunaan premedikasi antikolinergik secara teratur. Namun, sekarang jelas bahwa premedikasi dengan agen antikolinergik seperti atropin dan glikopirolat tidak selalu mencegah terjadinya TCR. Stratifikasi risiko berdasarkan jenis prosedur pembedahan, insiden, faktor risiko praoperasi dan intraoperatif serta perubahan dalam teknik anestesi dan pembedahan dapat dianggap sebagai langkah pencegahan. Barubaru ini, penggunaan anestesi topikal juga telah diusulkan untuk mencegah TCR. Akan tetapi, anestesi lokal secara berbeda memblokir berbagai serabut saraf dan karenanya tidak akan berguna dalam banyak kasus lain. Lebih dari itu, penggunaan anestesi lokal dekat area batang otak dapat menyebabkan komplikasi yang parah (anestesi batang otak lengkap). ${ }^{1}$

Salah satu langkah pertama dan terpenting dalam penatalaksanaan TCR adalah menginformasikan kepada ahli bedah agar penghentian stimulus dapat segera dilakukan. Seringkali tindakan itu membalikkan fenomena. Pemberian antikolinergik seperti atropin atau glikopirolat mungkin diperlukan dalam beberapa kasus dimana bradikardia parah atau menetap meskipun stimulus telah dihentikan. Namun, atropin hanya memblokir serabut kolinergik tetapi tidak sepenuhnya mencegah bradikardia atau hipotensi pada hewan, mungkin karena respons depressor trigeminalnya mencakup aktivasi serabut kardioinhibitor vagal dan penghambatan vasokonstriksi adrenergik setelah stimulasi listrik dari saluran trigeminal tulang belakang. Namun, dalam sebagian besar kasus yang dipublikasikan sebelumnya, pasien merespons untuk pengobatan di atas. Tetapi, kadangkadang, TCR mungkin refrakter terhadap metode pengobatan konvensional. ${ }^{1}$

Tabel 1. Penatalaksanaan TCR

\footnotetext{
Identifikasi dan modifikasi faktor risiko

Penilaian kedalaman anestesi

Pengobatan profilaksis dengan agen vagolitik atau perifer

blok saraf jika terjadi manipulasi saraf perifer.

Pemantauan kardiovaskular yang cermat selama anestesi, terutama pada mereka yang memiliki faktor risiko TCR.

Pengobatan kondisi saat itu terjadi: penghentian manipulasi, dan pemberian agen vagolitik dan adrenalin
} 
Dalam situasi yang jarang terjadi, mungkin diperlukan penggunaan vasopresor seperti epinefrin dan cardiac life support lainnya. Sebuah laporan baru-baru ini menyatakan bahwa anestesi dangkal merupakan faktor risiko untuk terjadinya TCR, tetapi juga penggunaan atropin lebih sedikit pada kelompok anestesi yang dalam untuk menggugurkan episode TCR. Dalam laporan ini, langkah kedua pengobatan meliputi penilaian kedalaman anestesi. Tindakan profilaksis untuk pencegahan TCR telah disarankan dengan infiltrasi anestesi lokal atau blok saraf yang menyampaikan rangsangan aferen. Arasho dkk., mengkategorikan manajemen pasien dengan TCR yang juga harus memasukkan penilaian kedalaman anestesi sebagai berikut:

\section{Etiopatogenesis dan Jenisnya}

Berbagai manifestasi episode TCR (bradikardia, hipotensi, asistol) serta subtipe TCR yang berbeda (perifer dan sentral) dapat bermanifestasi pada pasien yang sama. Asistol sementara juga dapat muncul selama penutupan kulit. Respon aliran simpatis yang berbeda dapat disebabkan oleh perbedaan kedalaman anestesi, yang digabungkan dengan berbagai bentuk stimulasi TCR mungkin berkontribusi pada respon hemodinamik yang berbeda pada pasien yang sama dan mengaburkan manifestasi klasik TCR. Secara mencolok, perubahan kardiovaskular dari fenomena TCR terutama dilaporkan karena stimulasi akut (perioperatif) saraf trigeminal. ${ }^{5}$
Gangguan jantung langka lainnya yaitu spasme koroner pada pasien bedah saraf mungkin merupakan manifestasi dari kejadian TCR. Sebagian besar kondisi bedah saraf, stimulasi dural memicu perubahan gelombang ST-T, takikardia ventrikel, dan fibrilasi ventrikel. Reseptor asetilkolin yang dimediasi vagal juga dikaitkan dengan perkembangan spasme. Meskipun sebagian besar kejadian spasme koroner bersifat sementara (beberapa menit hingga beberapa jam); namun, sangat sedikit yang juga berkembang kearah infark miokard perioperatif. $^{5}$

Pada awal penelitian TCR, hal ini biasa dijelaskan dalam prosedur bedah saraf. Setelah itu, juga dilaporkan selama maxillo-facial, ophthalmic, nasal, dental dan operasi lainnya. TCR adalah refleks batang otak kompleks yang mencakup saraf kranial, ganglion, dan berbagai nukleus. Jalur aferen dibentuk oleh saraf kelima, pusat relai pusat, inti batang otak, dan koneksi eferen melalui saraf kesepuluh. Ketika ada rangsangan (fisiologis, atau patologis) di sekitar divisi sensorik saraf kelima, sinyal diteruskan ke inti sensorik saraf trigeminal melalui ganglion Gasserian (Gambar 1). Jalur aferen berlanjut di sepanjang serabut saraf internuncial pendek dalam formasi retikuler untuk terhubung dengan jalur eferen di nukleus motorik saraf vagus. Hasil umum dari refleks ini adalah gangguan kardiovaskular negatif yang disebabkan oleh

Tabel 2. Subtipe TCR dan Manifestasi Klinisnya

\begin{tabular}{llllll}
\hline Subtipe Klinis & Trigger point & Laju Nadi & Tekanan Darah & Laju Nafas & $\begin{array}{l}\text { Motilitas } \\
\text { Gaster }\end{array}$ \\
\hline Perifer & $\begin{array}{l}\text { Stimulasi daerah } \\
\text { yang dipersyarafi } \\
\text { V1, V2 dan V3 }\end{array}$ & Bradikardi & $\begin{array}{l}\text { Hipotensi atau } \\
\text { normotensi } \\
\text { (hipertensi } \\
\text { pada reflex } \\
\text { diving) }\end{array}$ & Apnoe & Meningkat \\
Central & $\begin{array}{l}\text { Stimulasi bagian } \\
\text { intrakranial saraf } \\
\text { trigeminal }\end{array}$ & Bradikardi & Hipotensi & Apnoe & Meningkat \\
Ganglionik & $\begin{array}{l}\text { Stimulasi langsung } \\
\text { Ganglion Gasseri }\end{array}$ & $\begin{array}{l}\text { Bradikardi atau } \\
\text { takikardi }\end{array}$ & $\begin{array}{l}\text { Hipotensi atau } \\
\text { hipertensi }\end{array}$ & Apnoe & Meningkat \\
\hline
\end{tabular}

Keterangan: V1, V2, V3 : divisi V1, V2, V3 saraf ke lima.

Dikutip dari Singh GP.7 
rangsangan serabut depresor dari saraf vagus yang berakhir di miokardium. ${ }^{5}$ Meskipun mekanisme pastinya masih belum diketahui, banyak nukleus yang dijelaskan termasuk nukleus sensorik saraf trigeminal, nukleus trigeminal caudalis, nukleus parabrakial, medula oblongata ventro-lateral rostral, bidang retikuler meduler dorsal, dan nukleus paratrigeminal. Karena TCR adalah refleks otonom, ketidakseimbangan antara arus keluar parasimpatis dan simpatis terutama bertanggung jawab atas hasil akhir TCR. Biasanya, ada ko-aktivasi sistem saraf parasimpatis dan simpatis. Tiga manifestasi umum dari TCR termasuk bradikardia (aktivasi parasimpatis), vasokonstriksi (aktivasi simpatis) dan apnea (dimodulasi oleh sistem trigeminus di dalam batang otak). Namun, bradikardia yang cepat dan sementara, tetapi pemulihan hipotensi yang lebih lama dan sedikit tertunda, sebagian dapat dijelaskan oleh fakta bahwa serabut parasimpatis terutama menginervasi atrium dan jaringan konduksi, sedangkan serabut simpatis lebih tersebar luas ke seluruh jantung.

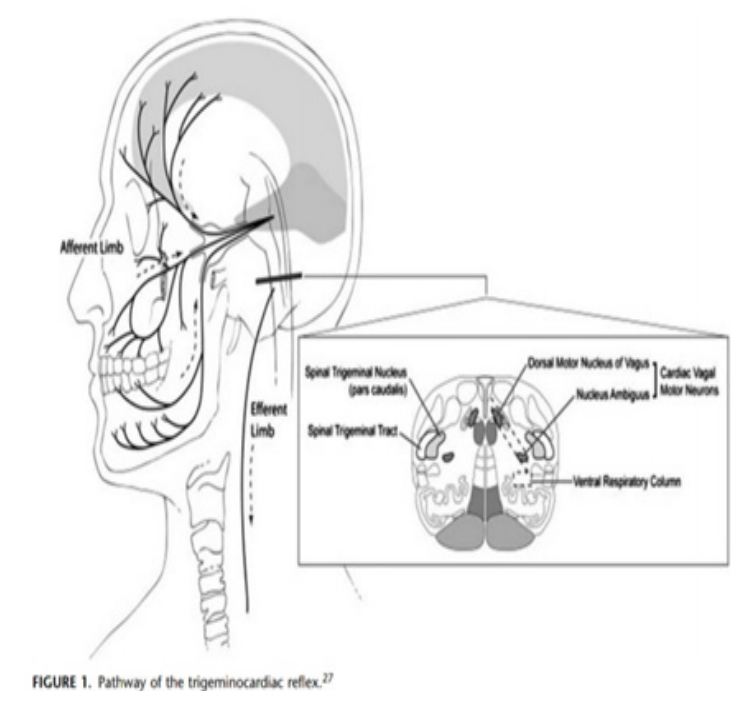

Gambar 2: Jalur trigeminocardiac reflex.

Dikutip dari: Chowdhury T. ${ }^{6}$

intrinsik yang ditandai dengan expiratory apnea, melambatnya HR, pengurangan aliran darah ekstremitas dan kulit serta peningkatan MABP. Ini ditimbulkan oleh stimulasi bagian atas muka oleh air dingin atau mukosa nasal (misalnya

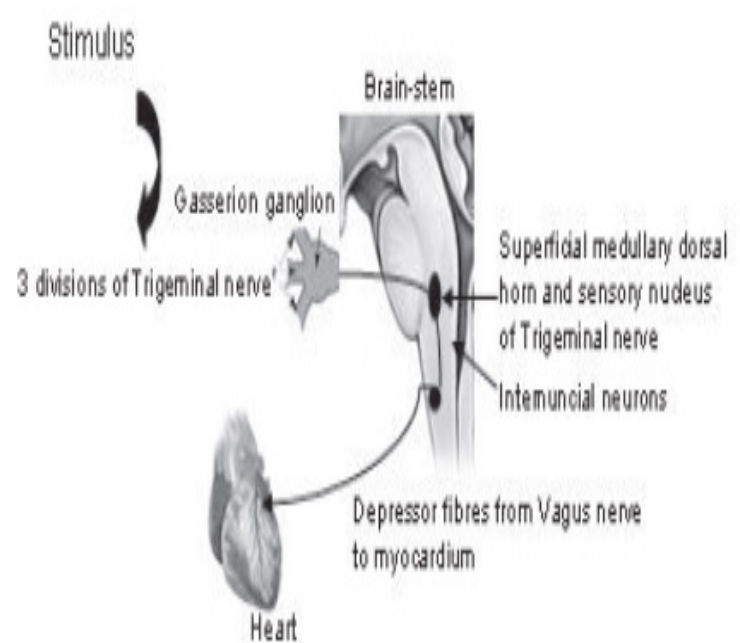

Gambar 3 Diagram skema yang menunjukkan mekanisme TCR

Dikutip dari Chowdury. ${ }^{1}$

Telah dikemukakan bahwa status mielinisasi saraf mungkin bukan faktor risiko utama, dan heterogenitas fenotipik dapat menjadi dasar kerentanan untuk aktivasi saraf otonom simultan. ${ }^{5}$ Berdasarkan definisi umum TCR, Schaller telah memasukkan berbagai periferal dan subtipe yang dirangsang secara terpusat ke dalam konsep TCR. ${ }^{2,6}$

Oculo Cardiac Reflex (OCR)

Oculo Cardiac Reflex sering dilaporkan pada operasi mata dan umumnya manifest sebagai bradikardi berat atau asistol. Oculo Cardiac Reflex paling sering terjadi pada operasi strabismus, akibat traksi pada otot ekstraokuler, namun juga bisa diamati selama manipulasi operasi lain dari struktur periokular yang dipersarafi oleh divisi oftalmikus saraf trigeminal. ${ }^{2,6}$

\section{Maxillomandibulocardiac Reflex (MCR)}

Respon refleks bradikardik juga telah diamati dan dijelaskan pada stimulasi saraf trigeminal divisi maksilar dan madibular selama operasi kraniomaksilofasial. ${ }^{2,6}$

Diving Reflex (DR)

Diving Reflex merupakan refleks batang otak 


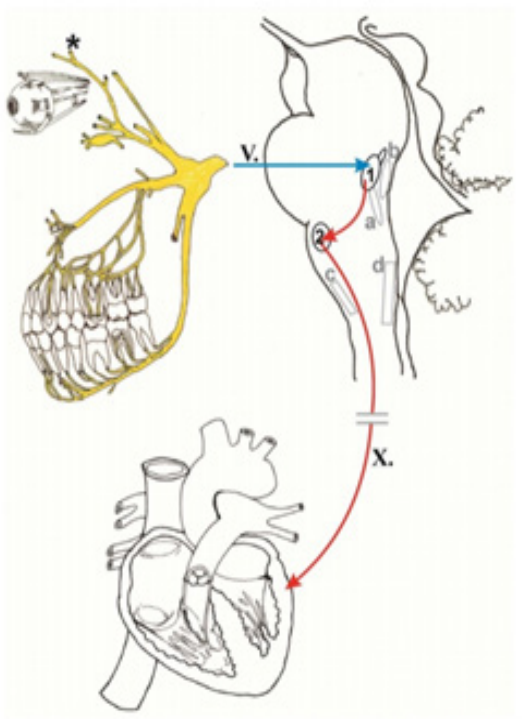

Gambar 4. Anatomi busur refleks trigeminokardiak mewakili tiga cabang dari saraf trigeminal yaitu saraf oftalmikus (CN V1) yang bertanggung jawab untuk mediasi OCR. Saraf maxilla (CN V2) dan mandibula ( $\mathrm{CN}$ V3) bertanggung jawab refleks maxillomandibulocardiac (MCR. Dikutip dari: Abdulazim A. ${ }^{2}$

amonia). Secara fungsional, DR telah dibuktikan sebagai mekanisme untuk menghemat oksigen., ${ }^{2,6}$

Pusat vs perifer

Baik OCR dan MCR dianggap mewakili subtipe fisiologis perifer dari TCR, misalnya OCR dan TCR sentral dikaitkan dengan bradikardia, akan tetapi, berbeda dengan TCR pusat, OCR tidak menunjukkan hipotensi. Demikian pula, MCR telah diamati terjadi tanpa disertai hipotensi, meskipun pemahaman ini telah ditantang oleh penelitian terbaru yang menunjukkan penurunan MABP pada MCR dan TCR perifer menunjukkan adanya refleks hipertensi. Dari sudut pandang fisiologis, TCR dan DR tampaknya sangat dekat terhubung, karena keduanya mendasari busur refleks batang otak yang serupa. Respon bradikardik eferen dari kedua refleks tersebut dikaitkan dengan pusat yang terletak di medula oblongata dan dimediasi oleh jalur parasimpatis. Demikian pula, vasokonstriksi perifer dilakukan melalui jalur simpatis eferen. Namun, pada TCR MABP menurun, tapi meningkat pada DR seperti yang diamati untuk TCR perifer. Temuan ini menunjukkan bahwa DR mungkin merupakan subformulir perifer dari TCR yang lebih jauh dan merupakan refleks lama filogenetik yang hanya ada secara menyimpang pada orang dewasa., ${ }^{2,6}$

\section{Relevansi Klinis}

Trigeminocardiac reflex adalah penyebab umum kegawatdaruratan jantung dalam intervensi bedah saraf elektif. Sebagian besar episode TCR bersifat sementara dan tidak secara signifikan mempengaruhi hasil neurologis pascaoperasi. Namun, penelitian lain menggarisbawahi sifat patologis TCR dan mencatat konsekuensi fungsional setelah episode TCR intraoperatif. Karena TCR dapat terjadi tanpa perubahan hemodinamik sebelumnya, penting untuk mengidentifikasi tanda peringatan yang mungkin mendahului TCR dan untuk lebih memahami pengaruh pada hasil klinis dari respon tersebut. Hasil studi prospektif menunjukkan bahwa biomarker serum iskemia mungkin berguna sebagai penanda pengganti untuk mencegah terjadinya TCR. Sebuah studi baru-baru ini juga mendukung bahwa episode TCR intraoperatif adalah terkait dengan hasil fungsional yang merugikan dalam operasi hipofisis. Mereka mengukur kadar hormon sebelum dan sesudah operasi hipofisis dan menemukan kekurangan hormon hipofisis pada kelompok TCR. ${ }^{1}$

\section{Operasi cerebellopontine angle}

Pada tahun 1999, Schaller et al., untuk pertama kalinya melaporkan TCR setelah stimulasi bagian tengah saraf trigeminal selama operasi cerebellopontine angle, dan memperkenalkan TCR ke komunitas bedah saraf. Sebanyak 125 pasien yang menjalani operasi cerebellopontine angle karena neoplasma dipantau sehubungan dengan terjadinya respons kardiovaskular otonom yang konsisten dengan TCR. Memang, 11\% dari pasien menunjukkan respon yang kemungkinan besar disebabkan oleh TCR. Pada saat membedah tumor di dekat saraf trigeminal di batang otak, HR dan MABP pasien menurun secara signifikan. HR rata-rata turun $38 \%$ dari rata-rata 76 denyut/menit sebelum manipulasi menjadi rata-rata 47 denyut/ menit selama prosedur, dan kembali ke rata-rata 77 denyut/menit setelah manipulasi. MABP turun 
$48 \%$ dari rata-rata $84 \mathrm{mmHg}$ sebelum manipulasi menjadi $44 \mathrm{mmHg}$ selama prosedur, dan kembali ke $82 \mathrm{mmHg}$ setelah manipulasi. Baik HR dan MABP kembali ke nilai normal (pra-manipulatif) setelah pembedahan. Pada tiga kasus ditemukan asistol dengan durasi 30 sampai 70 detik dan kembali ke ritme jantung normal dalam 90 hingga 180 detik setelah penghentian manipulasi. Dari 14 kasus, manipulasi bedah saraf trigeminal dekat batang otak menimbulkan efek spesifik dan tegas (tiba-tiba bradikardia dan hipotensi arteri). Meniadakan stimulus pemicu, seperti manipulasi di dekat atau pada saraf trigeminal, menyelesaikan efek tersebut dan pengulangan stimulus menyebabkan efek yang sama setiap saat. $^{2}$

\section{Operasi transsphenoidal}

Untuk menentukan sifat dan beratnya TCR selama operasi transsphenoidal, Schaller et al. mengamati 117 pasien yang dioperasi, dengan penekanan khusus pada kejadian dan faktor risiko TCR. Insiden TCR dalam seri ini adalah 10\% dengan tidak memperhitungkan subkelompok untuk parameter usia, jenis kelamin, histologi tumor, atau durasi dan distribusi gejala praoperasi. Selama preparasi septum hidung tidak ada pasien yang menunjukkan TCR. Namun terjadi penurunan HR dan MABP yang signifikan selama reseksi tumor lateral di dekat sinus kavernosus. HR rata-rata penurunan adalah $43 \%$ dari rata-rata $78 \pm 13$ denyut/menit sebelum manipulasi menjadi rata-rata $45 \pm 13$ denyut/ menit. Penurunan MABP rata-rata adalah 54\% dari rata-rata $86 \pm 8 \mathrm{mmHg}$ sebelumnya hingga $40 \pm 13 \mathrm{mmHg}$ selama manipulasi. Dalam sepuluh menit setelah penghentian stimulus dan tanpa pemberian antikolinergik nilai $\mathrm{HR}$ dan MABP kembali ke $77 \pm 9$ denyut/menit dan $82 \pm$ $8 \mathrm{mmHg}$. Nilai pasca prosedural tidak signifikan berbeda dari nilai dasar sebelum operasi. Dua pasien menunjukkan asistol selama 25-63 detik dan irama sinus kembali dalam 75-135 detik setelah akhir manipulasi bedah.

Menariknya, TCR terjadi secara signifikan lebih sering pada pasien dengan adenoma invasif grade III / IV, menurut klasifikasi Hardy yang dimodifikasi oleh Wilson ( $83 \%$ versus $22 \%$; $\mathrm{p}<0,001)$. Atas dasar itu, TCR terjadi selama persiapan di dekat sinus kavernosus dan sedang terkait dengan adenoma yang lebih invasif, yang berpotensi menyerang atau menekan kavernosa sinus. Simpulannya, TCR harus diperoleh dari struktur yang melewati sinus kavernosus. Dengan tidak adanya serat parasimpatis dan dengan yang pertama dan cabang kedua dari saraf trigeminal berjalan melalui sinus kavernosus (cabang dari saraf trigeminal mempersarafi dinding sinus kavernosus), tampaknya yang paling mungkin diamati respon otonom disebabkan oleh TCR. Ini telah digarisbawahi oleh Abou-Zeid et al, yang melaporkan kasus pasien yang perlu dioperasi kembali karena sisa adenoma hipofisis berdekatan dengan dinding sinus kavernosus kiri. Selama pembedahan sejumlah kecil tumor yang meluas melalui dinding sinus kavernosus kiri pasien menjadi sangat bradikardia dan terjadi periode asistol selama 30 detik, yang mana dengan cepat memerlukan atropin. Bradikardia dan asistol sementara juga pada pasien ini kemungkinan besar terkait dengan manifestasi TCR. ${ }^{2}$

\section{Dekompresi trigeminal mikrovaskular (prosedur Jannetta)}

Setelah terbukti terjadi TCR selama pembedahan di cerebellopontine angle dan hipofisis, masih ada pertanyaan tentang apakah TCR terjadi pada operasi bedah saraf lainnya. Schaller mengevaluasi 28 kasus pasien yang dilakukan microvascular trigeminal decompression ternyata $18 \%$ pasien dalam penelitian ini menunjukkan TCR selama operasi. Pada saat tindakan di sekitar saraf trigeminal, HR dan MABP pasien menurun secara signifikan. HR rata-rata turun $46 \%$ dari rata-rata 72 denyut/menit sebelum manipulasi menjadi rata-rata 39 denyut/menit selama prosedur, kembali ke rata-rata 75 denyut/menit setelah manipulasi dihentikan. MABP turun 57\% dari rata-rata $81 \mathrm{mmHg}$ sebelum manipulasi menjadi $35 \mathrm{mmHg}$ selama prosedur, kembali ke $84 \mathrm{mmHg}$ setelah manipulasi dihentikan. Satu pasien terjadi asistol selama 33 detik yang kembali ke ritme jantung normal dalam 83 detik setelah manipulasi bedah selesai. Semua kasus TCR terjadi saat memisahkan struktur mikrovaskuler dari radix sensoris saraf trigeminal. ${ }^{2}$ 


\section{Kliping aneurisma}

Baru-baru ini, Spiriev et al., telah melaporkan pasien yang datang dengan perdarahan subarachnoid (SAH) (Hunt dan Hess 2, Fischer III) akibat pecahnya aneurisma yang terletak di posterior communicating artery-internal carotid artery junction (PcomA-ICA). Setelah menempatkan klip di internal carotid artery (ICA), pasien mengalami serangan jantung mendadak yang berlangsung selama 30 detik. Mengacu bahwa terminal trigeminal ditemukan di semua pembuluh darah lingkaran Willis, ada kemungkinan bahwa respon yang diamati saat manipulasi menunjukkan kejadian TCR. ${ }^{2}$

Spiriev dkk. mereview literatur dengan mengacu pada terjadinya TCR pada prosedur clipping aneurisma dan menemukan tiga kasus lainnya yangmanaresponskardiovaskularpaling mungkin karena TCR. Tetap saja, harus ditekankan, bahwa disfungsi jantung termasuk infark miokard terjadi pada hingga 30\% pasien SAH dan telah dibahas akibat aktivitas berlebihan dari sistem saraf otonom yang tidak diketahui asalnya. Karena asistol itu jelas terkait dengan penempatan klip dan tidak dengan akibat perdarahan ulang pada pasien ini menunjukkan bahwa hal ini disebabkan oleh TCR daripada akibat disfungsi jantung yang terkait dengan SAH.2

\section{Pencegahan dan Pengobatan}

Risiko TCR selalu perlu dipertimbangkan jika dilakukan intervensi di wilayah saraf trigeminal. Dokter bedah harus memberi tahu ahli anestesi jika dia secara langsung mendekati saraf atau cabangnya. Trauma langsung ke jaringan saraf harus dikurangi seminimal mungkin karena manipulasi yang halus dan lembut cenderung tidak menimbulkan TCR. Faktor intraoperatif seperti anestesi ringan, hiperkapnia, hipoksia dan asidosis harus dikoreksi sebelum dimulainya manipulasi bedah karena berpotensi terjadi TCR. Pemantauan HR dan MABP secara menyeluruh dan konstan selama prosedur pembedahan memungkinkan ahli bedah untuk segera menghentikan manuver pembedahannya bila terjadi perburukan hemodinamik akibat TCR. Ini sebagian besar telah terbukti cukup untuk menghentikan refleks dan dalam memulihkan HR normal dan tekanan darah, tanpa perlu memberikan antikolinergik. ${ }^{2}$ Jika bradikardia dan hipotensi membandel terhadap penghentian manipulasi, lakukan pemberian antikolinergik intravena (atropin dan/atau glikopirolat). Bradikardi dan hipotensi pada TCR, bukan saja akibat dari stimulasi vagal yang kuat, tapi juga dari pengurangan tonus simpatetik. Dalam kasus ini, pasien tidak akan merespon vagolitik dan aplikasi epinefrin telah terbukti efektif, juga penekanan bahwa TCR mengandung komponen simpatik. TCR refraktori yang membutuhkan cardiac life support telah dilaporkan sebelumnya tetapi tampaknya jarang terjadi. ${ }^{6}$

Studi terbaru menunjukkan bahwa infiltrasi anestesi lokal atau blok saraf pada jalur aferen, dapat untuk profilaksis TCR perifer. Blok peribulbar menggunakan bupivaicaine pada pasien yang dioperasi ablasi retina, secara signifikan mengurangi kejadian dan melemahkan beratnya refleks. Dibandingkan dengan aplikasi anestesi lokal topikal pada anak-anak yang menjalani operasi strabismus, blok peribulbar efektif untuk profilaksis refleks. Kemungkinan blokade OCR, satu komponen TCR perifer, dapat dilakukan dengan anestesi lokal, namun, efek anestesi lokal terhadap kejadian MCR serta TCR sentral masih menjadi bahan perdebatan. ${ }^{6}$

Penelitian yang mempelajari efektivitas blokade reseptor muskarinik jantung perifer menggunakan atropin sulfat intravena dan konduksi tungkai aferen di ganglion siliaris dengan retrobulbar xylocaine hydrochloride. Mereka menemukan, bahwa setiap metode mampu mengurangi laju OCR menjadi 10\%-20\% dan refleks benar-benar ditekan saat kedua metode digabungkan. Namun, apa yang tampaknya layak dan efektif bagi TCR periferal tidak berlaku untuk TCR sentral. Ini mungkin disebabkan oleh fakta bahwa TCR sentral ditimbulkan oleh divisi sentral di dekat batang otak, tidak seperti TCR perifer, sirkuit refleksnya terletak hampir sepenuhnya intrinsik ke sentral. Dari perspektif mekanistik, manipulasi sentral dari saraf trigeminal dapat menyebabkan traksi batang otak itu sendiri atau outlet saraf mengakibatkan aktivasi busur refleks sentral 
intrinsik. Jadi, blok perifer dari saraf trigeminal atau salah satu cabangnya tidak efektif dalam mencegah TCR sentral. ${ }^{2}$

Perawatan terbaik dan lebih efektif untuk TCR masih menjadi bahan perdebatan intensif. Pilihan manajemen pertama dan terpenting untuk TCR harus diperhatikan potensi bahaya dan untuk meminimalkan stimulasi mekanis/termal saraf selama prosedur intervensi apapun di dalam atau di sekitar dasar tengkorak. ${ }^{5}$ Menurut pengalaman empiris TCR, bukti dan rekomendasi saat ini sebagai berikut: identifikasi dan modifikasi faktor risiko, pengobatan profilaksis dengan agen vagolitik atau blok saraf perifer jika terjadi manipulasi saraf trigeminal perifer, pemantauan kardiovaskular yang cermat selama anestesi terutama pada mereka yang memiliki faktor risiko TCR, pengobatan kondisi saat itu terjadi, penghentian manipulasi, infiltrasi anestesi lokal atau penyumbatan saraf, pemberian agen vagolitik atau adrenalin (perifer $>>$ sentral $>>$ ganglion). ${ }^{5}$

Jika bekerja di sekitar saraf trigeminal atau cabangnya, harus dilakukan komunikasi secara intensif antara ahli bedah dan ahli anestesi. Dilakukannya pemantauan hemodinamik intraoperatif secara kontinyu terbukti menjadi media yang tepat untuk menghentikan setiap manuver intervensi dengan segera setelah tanda-tanda pertama terjadinya TCR. Teknik ini telah terbukti cukup untuk mengembalikan ke hemodinamik normal tanpa perlu tambahan pengobatan (antikolinergik). Jika hipotensi arteri terkontrol sudah direncanakan sebelum operasi dilakukan selama prosedur intervensi, profilaksis TCR lebih baik dilakukan dengan infiltrasi anestesi lokal atau blok saraf yang menyalurkan rangsangan aferen. ${ }^{5}$ Penelitian pada 60 pasien yang secara acak menerima bupivacaine atau morfin intravena dan mempelajari kejadian dan tingkat keparahan OCR, selain secara signifikan mengurangi kejadian OCR $(30 \%$ vs $70 \%$ ), bupivakain peribulbar juga mengurangi keparahan refleks. Gupta dkk. mempelajari efek blok peribulbar dibandingkan dengan aplikasi anestesi lokal topikal pada anak-anak yang dijadwalkan untuk operasi strabismus. Mereka menemukan bahwa kejadian dan keparahan OCR intraoperatif berkurang secara signifikan pada anak-anak yang menerima blok peribulbar. Misurya dkk. mempelajari efektivitas profilaksis atropin sulfat intravena yang memblokir reseptor muskarinik perifer di jantung dan retrobulbar xylocaine hidroklorida, yang memblokir konduksi di ganglion siliaris pada tungkai aferen OCR. Dalam studi ini, baik atropin dan retrobulbar xylocaine menurunkan laju OCR menjadi 1020\%. ${ }^{5}$ Tapi, ketika kedua metode digunakan bersama-sama, mereka mampu sepenuhnya

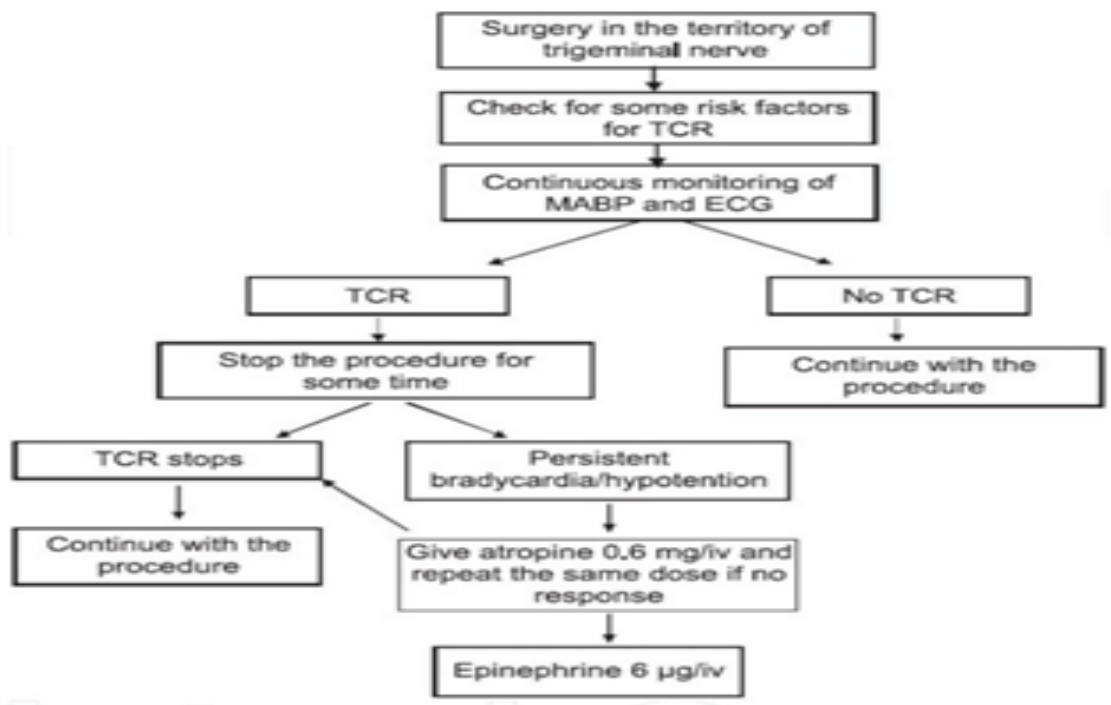

Gambar 6: Algoritma pengobatan TCR

Dikutip dari: Chowdhury T. ${ }^{5}$ 
menekan OCR. Jika tidak ada kontraindikasi terhadap antikolinergik intravena, atropin dan/ atau glikopirolat intravena dapat digunakan untuk mencegah sebagian dari TCR. Hunsley dkk. mengevaluasi kemanjuran atropin dan glikopirolat intravena dalam pencegahan OCR pada anak-anak yang dioperasi untuk strabismus. Mereka menguji dosis yang berbeda dari kedua obat tersebut, glikopirolat 5 dan $7,5 \mathrm{mg} / \mathrm{kg}$ dan atropine 10 dan $15 \mathrm{mg} / \mathrm{kg}$. Secara keseluruhan, ada penurunan angka bradikardia sebesar 23,8$33,3 \%$. Tapi dosis yang lebih tinggi dari kedua obat tersebut, atropin $15 \mathrm{mg} / \mathrm{kg}$ dan glikopirolat $7.5 \mathrm{mg} / \mathrm{kg}$ i.v., diberikan 5 menit sebelum induksi anestesi, tidak cukup untuk melindungi sepenuhnya terhadap OCR pada anak-anak. ${ }^{5}$

Penelitian yang dilakukan untuk mengevaluasi kemanjuran agen vagolitik (atropin dan glikopirolat) intravena atau intramuskuler pada anak-anak yang menjalani operasi strabismus, menemukan bahwa pemberian antikolinergik intravena dan intramuskuler dapat menurunkan kejadian OCR. Frekuensi keseluruhan adalah sekitar 40\% (62 dari 160 pasien), tetapi $90 \%$ terjadi pada pasien yang tidak menerima antikolinergik. Pemberian obat antikolinergik, bahkan melalui jalur intramuskuler, menurunkan frekuensi OCR, dan glikopirolat $10 \mathrm{mg}$ per $\mathrm{kg}$ menjadi yang paling manjur. Sebagai konsekuensinya, pemberian antikolinergik telah terbukti tidak efektif sepenuhnya dalam mencegah TCR. Penggunaan atropin saat ini dipertanyakan karena penghambatan kolinergik berkurang, akan tetapi, tidak mencegah bradikardia atau hipotensi secara total. Selain itu, atropin dapat menyebabkan aritmia itu sendiri, terutama bila dipakai halotan sebagai anestetika utama dan karenanya dosis harus dipilih dengan cermat. ${ }^{5}$

Prabhakar dkk., melaporkan seorang perempuan berusia 48 tahun yang mengalami bradikardia berat dan hipotensi selama kraniotomi karena konveksitas parietal meningioma; dia tidak responsif terhadap atropin dan berhasil ditangani dengan epinefrin. Aksi adrenalin adalah meningkatkan resistensi perifer melalui adrenoseptor alfa-1 vasokonstriksi, sehingga darah dialirkan ke inti tubuh, dan respon adrenoseptor alfa-1 yang meningkatkan denyut jantung dan output. Ini merupakan laporan kasus penting untuk menilai fakta bahwa TCR mungkin refrakter terhadap atropin dan vagolitik lain dan mungkin lebih perlu dikelola dengan epinefrin. ${ }^{5}$ Satu penelitian kombinasi farmakologis yang mempelajari keefektifan blokade reseptor muskarinik jantung perifer menggunakan atropin sulfat intravena dan konduksi cabang aferen di ganglion siliaris dengan retrobulbar xylocaine hydrochloride, ditemukan bahwa setiap metode mampu mengurangi laju OCR hingga $10 \%$ sampai $20 \%$ dan refleksnya bisa sepenuhnya ditekan ketika kedua metode digabungkan. Namun, apa yang tampaknya layak dan efektif untuk TCR perifer, tidak berlaku untuk TCR sentral.

\section{Simpulan}

Trigeminocardiac reflex adalah fenomena umum pada mamalia dan dapat muncul dari perubahan fisiologis ringan hingga gangguan kardiovaskular patologis yang berat. Karena laporan terbaru terkait TCR berasal dari berbagai kondisi bedah dan non-bedah, sangat penting untuk mengetahui refleks unik ini secara mendetail. Hal ini tentunya akan membantu pemahaman yang lebih baik tentang TCR dan mengembangkan tidak hanya model diagnostik di masa depan tetapi juga model terapeutik untuk menangani berbagai gangguan neurologis dan jantung. Tetapi pengetahuan yang lebih baik tentang TCR juga memungkinkan untuk lebih memahami fungsi fisiologis jantung.

\section{Daftar Pustaka}

1. Chowdhury T, Rosemann T, Schaller B. Trigeminocardiac reflex: an overview. REV ARGENT CARDIOL 2018;86:276-82

2. Abdulazim A, Stienen MN, Sadr-Eshkevari P, Prochnow N, Sandu N, Bohluli B, et al. Trigeminocardiac reflex in neurosurgerycurrent knowledge and prospects. www. intechopen.com

3. Meuwly C, Chowdhury T, Sandu N, Golanov E, Erne P, Rosemann T, Schaller B. Definition 
and diagnosis of the trigeminocardiac reflex: a grounded theory approach for an update. Frontiers in Neurology 2017;9

4. Amirjamshidi A, Abbasioun K, Etezadi F, Ghasemi SB. Trigeminocardiac reflex in neurosurgical practice: report of two new cases. Surg Neurol Int 2013;4:126

5. Chowdhury T, Arasho B, Sandu N, Meuwly $\mathrm{C}$, Schaller B. The trigeminocardiac reflexan example of reflexive heart rhythm change. INTECH http://dx.doi.org/10.5772/60215

6. Chowdhury T, Mendelowith D, Golanov E, Spiriev T, Arasho B, Sandu N, et al. Trigeminocardiac reflex: the current clinical and physiological knowledge. J Neurosurg Anesthesiol 2015;27:136-47

7. Singh GP, Chowdhury T. Brain and heart connections: The trigeminocardiacreflex! J Neuroanaesthesiol Crit Care 2017;4:71-7.

8. Bhattacharjee A, Rajaram P, Khatua A, Rudresh KB, Krishnamurthy PB. Two episodes of trigeminocardiac reflex during a pan facial fracture surgery, a rare phenomenon - case report and review of literature. Journal of Clinical and Diagnostic Research. 2017 Sep, 11(9): ZD01-ZD03

9. Morgan E, Kanu OO, Adetunmbi R, Adesida A. Trigemini cardiac reflex: a finding in skull base surgery that could be catastrophic-a review of literature. Biomed J Sci \& Tech Res 2018, 7810-12

10. Meuwly C, Golanov E, Chowdhury T, Erne P, Schaller D. Trigeminal cardiac reflex: new thinking model about the definition based on literature review. Medicine 2016;94(5):1-9

11. Devakumari S, Vijhayapriya T. Trigeminal cardiac reflex and its importance in maxillofacial surgery-a review. IOSR-JDMS 2013;12(2):7-11

12. Arasho B, Sandu N, Spiriev T, Prabhakar $\mathrm{H}$, Schaller B. Management of the trigeminocardiac reflex: fact and own experience. Neurology India 2009;57(4):37580 